об'єднаних територіальних громад. URL: https://storage.decentralization.gov.ua/uploads/library/file/23/STRAT EGIC_PLANNING_MANUAL_standard_version_9MB.pdf (дата звернення: 05.11.2020).

6. Про схвалення Концепції реформування місцевого самоврядування та територіальної організації влади в Україні : Розпорядження Кабінету Міністрів України від 01.04.2014 № 333-p. URL: https://zakon.rada.gov.ua/laws/show/333-2014-p (дата звернення: 05.11.2020).

DOI https://doi.org/10.30525/978-9934-26-005-6-7

\title{
ПІДВИЩЕННЯ ЕФЕКТИВНОСТІ \\ ПУБЛІЧНОГО УПРАВЛІННЯ ЗА РАХУНОК ВИКОРИСТАННЯ ПЕРЕДОВИХ ІНФОРМАЦЙНО-КОМУНІКАТИВНИХ ТЕХНОЛОГІЙ
}

\section{Кочугурна Ю. В.}

здобувач освітнього ступеня «магістр»

Навчально-методичного иентру післядипломної освіти та підвищення кваліфікації

Дніпровського національного університету імені Олеся Гончара, головний спеціаліст Відділу документального забезпечення та контролю управління з загальних питань виконавчого апарату

Дніпропетровської обласної ради м. Дніпро, Украӥна

Проблеми підвищення ефективності публічного управління за допомогою інформаційно-комунікативних технологій надзвичайно актуальні, адже використання комп'ютерної та комунікаційної техніки підвищує якість і швидкість обробки та передавання інформації, обсяг якої невпинно зростає. 
Прийняття управлінських рішень повністю залежить від документів. Починаючи 3 документів, які містять інформацію для прийняття рішень і закінчуючи самим рішенням, яке також оформлюється у вигляді документів. I цей документопотік може бути настільки великим, що це буде заважати основному змісту діяльності. Часто це призводить до порушення строків розгляду питань, неефективності роботи та недостатньої керованості організації.

Інформатизація органів публічної влади через широке застосування інформаційно-комунікаційних технологій, що характеризується підвищенням швидкості оброблення інформації відбувається перш за все через електронне урядування та його інструмент - електронний документообіг.

Під електронним документообігом у публічному управлінні розуміється комплекс заходів, що здійснюється в органах державної та виконавчої влади за допомогою сучасних інформаційно-комунікаційних технологій для створення, передавання, пошуку, виконання i контролю документів відповідно до затверджених правил, координації завдань між людьми та синхронізації даних.

Розвиток цифрової трансформації України, становлення інформаційного суспільства, впровадження технологій електронного урядування та всебічна цифровізація всіх процесів, потребують запровадження ефективного електронного документообігу. Функціонування органів публічного управління неможливе без інформаційної інфраструктури, наявних цифрових засобів для опрацювання значних масивів різної інформації. Надходження інформації, процес іï обробки та відображення результатів аналітичного опрацювання, а також прийнятих на ii основі управлінських рішень, переважно відбувається у вигляді електронних документів, що вимагає оптимізації документаційного забезпечення управління органів публічної влади шляхом впровадження систем електронного документообігу.

Електронний документообіг об'єднує в єдиний інформаційний простір усі документаційні системи. Це здійснюється зі збереженням традицій діловодства та якості 
роботи 3 документами. Подібна інтеграція здійснюється за допомогою надійного сховища та систем документообігу, які взаємодіють 3 ним. Необхідний пошук і відбір інформації при підготовці матеріалів забезпечується зберіганням всіх документів у єдиному сховищі. Однак при підготовці нових матеріалів важливим етапом $є$ робота 3 архівними документами. Інтеграція архіву електронного документообігу у єдиний інформаційний простір організації дозволить зробити доступ до архівних матеріалів оперативним і ефективним.

Електронний документообіг забезпечує:

- значну економію витратних матеріалів та часу, що витрачається на передавання, розмножування, пошук i розповсюдження документів;

- раціональне використання часу державних службовців, представників вищої і середньої управлінської ланки;

- полегшення роботи 3 електронними документами, внесені правки та розроблені проекти документів легко і 3 мінімальними затратами часу стають доступними для всіх зацікавлених сторін;

- багаторазове пришвидшення процесів узгодження остаточних документів та ухвалення відповідних рішень.

Тому електронний документообіг повинен стати основним механізмом організації взаємодії між органами державної влади та органами публічного управління, громадянами і суб'єктами господарювання. Впровадження інформаційно-комунікаційних технологій сприятиме створенню умов для досягнення європейських стандартів якості послуг, відкритості та прозорості діяльності органів державної влади та органів місцевого самоврядування. Це має забезпечити значне підвищення ефективності публічного управління і є одним із визначальних факторів трансформаційних перетворень у діяльності органів державної влади та органів місцевого самоврядування.

\section{Література:}

1. Мельничук Л. І., Головченко М.М. Питання впровадження електронного документообігу в органах державної влади. 
Вчені записки ТНУ імені В. І. Вернадського. Серія: Філологія. Соціальні комунікаџіï. 2019. Т. 30 (69). № 1, Ч. 2. С. 154-159.

2. Асєєв Г.Г. Управління сучасним документообігом: теорія, структура, методи / Г.Г. Вісник Книжкової палати. Київ, 2004. № 4. C. 17-19.

DOI https://doi.org/10.30525/978-9934-26-005-6-8

\title{
STRATEGIC COMMUNICATIONS INTERDEPARTMENTAL COOPERATION IN EDUCATION AND SCIENCE AMONG LEADING EDUCATIONAL ESTABLISHMENTS OF UKRAINE
}

\author{
Kushnir V. O. \\ Candidate of Sciences in Public Administration, \\ Doctoral Student at the Educational and Research Centre \\ for Strategic Communications in the sphere \\ of National Security and Defence \\ The National Defence University of Ukraine \\ named after Ivan Cherniakhovskyi
}

\section{Izhutova I. V.}

Chief of Training Section of the Educational and Research Centre for Strategic Communications in the sphere of National Security and Defence The National Defence University of Ukraine named after Ivan Cherniakhovskyi

Kyiv, Ukraine

Reforms of military education in line with implementation of NATO educational standards, principles, and best practice are one of the priorities of the Ukrainian armed forces development.

The Presidential Decree of Ukraine «On decision of the National Security and Defence Council of Ukraine dd May 20, 2016 «On 